various organizations. Grants were also made for otological research, for economic research at the Brookings Institution and the National Bureau of Economic Research, and for various educational projects, including one to the American Association for the Advancement of Science for science programming on television.

Science and Technology for the Benefit of the Lessdeveloped Areas

A NARRATIVE account of the United Nations Conference on the "Application of Science and Technology for the Benefit of the Less Developed Areas" (Nature, 197, 1135; 1963), held in Geneva in February 1963, is being issued in English in eight volumes. The first of these, World of Opportunity, has now been published, and the remaining volumes deal successively with natural resources; agriculture; industry; people and living-population, health, nutrition, rural development, urbanization; education and training; science and planning. The eighth volume includes the plenary proceedings of the Conference, a complete list of Conference papers and of the reports of Secretary-General of Conference and the rapporteurs, and subject index to all volumes. The first volume also includes a list of contents of the rema ning volumes. It is in three parts, the first, "The Changing World", setting the general background of the Conference, the second describing the Conference at work, including a summary of the discussions in the twelve sections of the agenda, and the third outlining what has to be done both by way of preparation and in seizing the opportunities. This first volume gives a very readable concise account of the whole Conference which may well meet the needs of those who are not concerned with specific activities or fields. It is essentially self-contained (United Nations. Science and Technology for Development: Report on the United Nations Conference on the Application of Science and Technology for the Benefit of the Less Developed Areas. Volume 1: World of Opportunity. Pp. viii +267. New York: United Nations, 1963. 6 dollars).

\section{Technical and Vocational Training in France}

UNDer the title Social Promotion: The Technical and Vocational Training of Adults in France, the French Embassy has issued a paper describing the opportunities and methods of training designed to assist the social advancement of adult workers by improving their skills or helping them to transfer to trades or occupations offering better prospects (Pp. 20. London: Ambassade de France, Service de Presse et d'Information, 1963). Some 226,300 workers were trained under such schemes in 1962, and for 1963 the figure is estimated at 280,000 . There are three grades of training: at the first level preliminary vocational training for a job as a specialized worker or further training with the view of employment as a skilled worker; at the second, training of highly skilled workers, technicians, foremen and junior management; and at the third, preparatory training of senior technicians, engineers and management staff. Training under social promotion is co-ordinated under a delegategeneral and a co-ordinating committee, the secretary of which is attached to the Prime Minister. There are also departmental and regional committees. Many training classes or centres for this purpose operate under the Ministry of Education. However, there are also some 125 centres of accelerated vocational training under the Ministry of Labour, and company centres have been set up by public services and private companies. Financial aid is given to workers attending full-time social promotion courses. For the next few years, besides developing part-time and full-time training courses, greater use is expected to be made of indirect educational techniques, such as radio, television and correspondence courses, with greater decentralization and co-ordination, continued basic studies and development of information activities.
The organization of technical education and vocational training of the young in France is described in a further paper (The Technical Education and Vocational Training of the Young in France. Pp. 20. London: Ambassade de France, Service de Presse et d'Information, 1963). In 1961-62, 495,000 pupils received technical edueation, or 51 per cent of the young people receiving vocational training, apprenticeship with $\mathbf{4 7 9 , 0 0 0}$ accounting for 49 per cent. At present, pupils who leave school at fourteen can either become pupils in a State or private technical institution or train in a company or with an artisan under articles of apprenticeship. Vocational training at present includes short, intermediate or longtraining courses, but when, in 1967, the school-leaving age is raised to sixteen, the short vocational courses will be open to all children between the ages of eleven and sixteen. There are 31 institutions for training engineers, 17 of which are State institutions, and all are empowered to award a diploma; 2,983 were awarded in 1961. Commercial higher education is given in 23 recognized private institutions, 15 higher commercial schools and other institutions. Apprentices are articled for three years and then sit for an examination leading to the award of a certificate of completion. Vocational training in industry and commerce is financed in part by an apprenticeship tax fixed at 0.4 per cent of the wages and salaries paid.

\section{The Leicester Museums and Art Gallery}

THE fifty-seventh annual report of the Museums and Art Gallery, Leicester, for 1962-63, in an attractive format, is a record of progressive work in all departments (Pp. 39. Leicester: City of Leicester Museums, 1963). The most important event during the year was the completion of the building on the Jewry Wall site. The upper floors were finished in time for the Vaughan College to start the winter session, but the Museum gallery below was not handed over until later and much remains to be done before the Museum of Archrology can be opened to the public. At the Newarke Houses a provisional display of items from the Museum of the Royal Leicestershire Regiment has been set up in two rooms, pending the acquisition of the Newarke Gateway. A clay mineral, allophane, has been collected from the Middle Lias Marlstone, near Tilton, where it was found coating joint surfaces in the rock.

\section{National Collection of Yeast Cultures}

IN 1948 the Institute of Brewing assumed responsibility for the yeast cultures which formed part of the National Collection of Type Cultures. The third edition of the catalogue, National Collection of Yeast Cultures, contains a total of nearly 900 strains, nearly double the number listed in the previous (1956) edition (National Collection of Yeast Cultures. Catalogue of Cultures maintained at the Brewing Industry Research Foundation, Nutfield, Surrey. Third edition. Pp. 51. Nutfield, Surrey: Brewing Industry Research Foundation: 1963). One of the new groups consists of strains which have been deposited as being of known genetical constitution with respect to certain properties. The members of this group are mostly haploid strains or hybrids which have been derived from various species of Saccharomyces. All the yeasts are subcultured regularly and each culture is examined at intervals of not more than one year to ensure that it continues to correspond with the original descrip. tion. Cultures can be supplied at charges recommended by the U.K. Committee on Culture Collections. Enquiries should be addressed to the Director, Brewing Industry Research Foundation, Lyttel Hall, Nutfield, Redhill. Surrey.

\section{The Zoological Society of London :- Awards}

THE Zoological Society of London has made the following awards, which will be presented by H.R.H. The 